\title{
MYSTIFICATION IN CZECH CINEMATOGRAPHY AND CZECH CULTURE
}

\author{
ANNA BRZEZINSSKA \\ brzezinska.ann@gmail.com \\ University of Wrocław, Poland
}

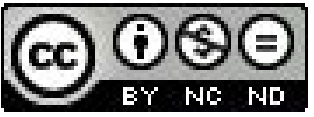

\begin{abstract}
The article concerns the issue of mystification and hoax in Czech culture. It demonstrates historical aspects of this phenomenon and, basing on the example of various cultural texts, shows that the mystification as a means of artistic expression is deeply rooted in Czech culture. Surrealistic and illogical themes that are characteristic for Czech humour are used by artists, especially filmmakers, in creating successive mystifications. The article examines films such as Oil Gobblers (1988), Year of Devil (2002), Czech Dream (2004), Jara Cimrman Lying, Sleeping (1983), in order to analyse the role of this phenomenon in both films that speak of mystification and the ones that are mystifications themselves.

Key words: hoax, mystification, mockumentary, Czech culture, Oil Gobblers, Year of Devil, Czech Dream, Jara Cimrman Lying, Sleeping, Jára Cimrman

In Czech cinematography, literature and theatre the theme of mystification is used frequently. It usually takes the form of a convention in which the whole nation participates, just as it happened in the case of Jára Cimrman, a fictional brilliant inventor in whose authenticity all Czech people believed and who to be recreated in other incarnations.

There are a few Czech films that speak of or are mystifications themselves, for example Oil Gobblers (1988), Year of Devil (2002) and Czech Dream (2004). A film about Czech national genius also had to be made, so in 1983 Jara Cimrman Lying, Sleeping was released. In order to take a closer look at the phenomenon of these and other mystifications one should analyse certain historical events and cultural texts by Czech artists first.

Mystification, in common meaning, is a pejorative word. Alex Boese (2003) compared it to lying, cheating, misrepresenting and making up. A. Boese also put forward criteria for the definition of mystification: it has to contain the quality of drama, scandal or sensation and should be unparalleled and ingenious. One cannot call something a mystification unless it is spread among the media and becomes known to all members of society. A mystification should have a social quality, influence a wide group of people and appear credible. What is important, moreover, is its intentionality; mystification is a conscious act which assumes that as people as possible should be deceived by it. What makes it different from fairytales or urban legends is its apparent realism, while the purpose of fairytales is to arouse imagination without misleading. Since a reader is conscious that a story is fictional, they will not resent the author for cheating them (Boese, 2003, pp. 13-16).
\end{abstract}


According to A. Boese, nowadays mystifications are common and ubiquitous. The reason for that is the technological progress that resulted in democratisation of life and the increasing significance of the new media. These, swift and having access to information from the whole world, consciously spread false information in order to increase the number of receivers. Moreover, the process of democratisation enabled everyone to take part in a public discourse, appear television, which, in turn, created a flow of information between artists, journalists, showmen (who possessed the privilege of creating mystification) and ordinary people. The easiest way to become famous is to demonstrate an interesting set of events, especially a tragic one, and introduce it to the media. Currently the Internet constitutes means of achieving fame quickly. The purpose of mystification is not only to become a well known person, but also to earn money and make business. Paradoxically, the freedom of speech makes it not only easier to become a cheater, but also to be cheated (Boese, 2003, pp. 13-16).

Henryk Markiewicz was another scholar to write about mystifications. According to his definition, they are "literary or paraliterary texts that are composed in such a way as to lead a reader into false conclusions concerning the author, time and place of the text, its identity and mode of discourse" (Markiewicz, 2003, p. 73). One can notice certain considerable differences between the definitions of A. Boese and H. Markiewicz. The former referred to the contemporary culture dominated by the new media, which present every believable story and present it as the truth. The latter speaks specifically of literature and film. Literary mystification brings no negative consequences that a fictional story in television can have. In the case of literature the mystifications are carried out for fun (both author and reader's), fame, fair profit, or in order to try something new. Deceptions in literature that are malicious or intended for an author's profit only are called literary frauds. Combining those two understandings of the issue, one can assume that nowadays mystification is, above all, something that induces a receiver into error in order to amuse them (Markiewicz, 2003, p. 73). This error should be extraordinary, absurd, creative and constitute a double game with the receiver. Watching a film itself introduces audience into a kind of a play; a director tells them that everything they will see is fictional. Mystification is a double game, since it makes receivers believe that what they will see is true.

There is a word in English language that is a synonym of mystification - hoax. Hoax is manipulation and misleading in which one can observe cultural, political and social aspects. What is important, hoaxes are often a critique of the contemporary world and culture, a fabrication of reality or creation of fiction on a great scale in order to amuse the audience. Hoax can be malicious; it can show the naivety of people and how prone to manipulation they are. Hoax is a word that is related to deception, wit and jokes. Creating such a form of entertainment, an author has to bear in mind the consequences of their joke: the panic or mass hysteria that it can evoke. The word itself comes probably from the incantation hocus pocus (Castagnaro, 2009, pp. 12-14). There is no direct equivalent of hoax in Polish or Czech language. Czech people use English hoax (though it is only present in common Czech language), but more often they use mystifikace. In Polish only the word mistyfikacja 
is used. Since the meanings of hoax and mystification are similar, I will use them as synonyms.

There is a multitude of examples of mystifications in Czech culture. Some people even consider it to be a national genre. One of the famous cases of frauds in Czech history was the mystification from the beginning of $19^{\text {th }}$ century The Manuscripts of Dvưr Králové and of Zelená Hora (cs. Rukopis Královédvorský a Rukopis Zelenohorský) written by Václav Hanka and Josef Linda in 1817. V. Hanka allegedly found two literary artefacts from the medieval times. The Manuscripts of Dvi̛r Králové contained a rhymed chivalrous epic and was dated $13^{\text {th }}$ century. The second one, The Manuscripts of Zelená Hora, was a jural act from about $9^{\text {th }}-10^{\text {th }}$ century (Tarajło-Lipowska, 2010, p. 100). Czech state, conquered by Habsburgs after the Battle of White Mountain in 1620 and affected by re-catholisation after the period of Jan Hus's reformation, underwent germanisation. Czech language was banned in schools and departments, preserved mainly in the countryside, while townsmen started to communicate in German. The period of Czech National Revival was the time when Czech language - its grammar, vocabulary and spelling principles - was created anew. Since it was the language of the lower class, it had no expressions that literature could make use of. The mystification was prepared by two Renaissance artists: V. Hanka and J. Linda of nearly patriotic nature. They belonged to the group of Czech writers who started the reconstruction of their mother tongue. They needed something that could awake national ambitions among their fellow countrymen, not only those from upper, but also from the lower class. In these times of search for national identity the manuscripts were supposed to be evidence for Czech people's history and medieval literature. This mystification, according to H. Markiewicz's definition, can be considered literary fraud. While mystification usually stems from artistic aspirations, fraud is manipulation that is supposed to change receivers' views; it is usually unethical, even if it is motivated ideologically and intended to underpin national pride, as it happened in case (Markiewicz, 2003, p. 73). The manuscripts remained in Czech national thought for a long time. It was one hundred years later that the mystification was exposed, to which Tomáš Garrigue Masaryk contributed.

The following Czech mystifications belonged to the artistic field and were intended to arouse society and usually to amuse it. They were often hoaxes that took the form of happenings: in a fun and artistic manner they brought up a social issue, encouraging as many people as possible to participate. An example of such a mystification was the establishment of The Party of Moderate Profress Within the Bounds of Law (cs. Strana mírného pokroku v mezích zákona) by Jaroslav Hašek and his friends after the results of by-election for the Vienna parliament in 1911 were announced. The party's actions were parodistic, comic and consisted of writing articles, delivering speeches and organising mass meetings (Tarajło-Lipowska, 2010, p. 243).

The most famous and structurally complex mystification of artistic and humorous character was the creation of J. Cimrman by Ladislav Smoljak and Zdeněk Svěrák. J. Cimrman was considered the greatest national hero and patriot (Joniak, A. 2009, p.203). The cultural phenomenon of this fictional character resulted from 
the fact that it was reflected in different fields of art: cinematography, literature, theatre, sculpture, photography and, aside from these, it even left an imprint on language.

For the first time J. Cirmrman appeared in Jára Cimrman Theatre in Prague. Most plays that included this character were written by L. Smoljak and Z. Svěrák. As said Václav Havel, it was a kind of dramaturgy that could be placed between operetta and Henrik Ibsen's plays (Szczygiel, 2012). Usually the plays, full of verbal humour and the aestheticism of nonsense, consisted of a parody of the academic lecture and consequently showed yet more previously uknown talents of J. Cimerman (Tarajło-Lipowska, 2010, p. 387). Currently the theatre is so popular that once the tickets are available for sale, they are sold out within few hours. The plays were also broadcasted live during The Spider Non-Alcoholic Wine Bar (cs. (Nealkoholická vinárna u Pavouka) radio programme. Listening to it for the first time in 1966 many Czech people actually believed in the discovery of texts written by the new national hero (Szczygiel, 2012).

It is difficult to answer the question who this famous Czech character was not. Above all, he was a genius, an inventor, an andragogist and pedagogist (Smoljak, \& Svěrák, 1993), a theatre director, a musician, a composer, a philosopher, a traveller, a sportsman, a historian, a doctor (Smoljak, Svěrák, \& Weigel, 2009), a skier, a dentist, a friend of Albert Einstein's, an internet pioneer and a librettist (Szczygieł, 2012).

His activity was of an extent so large that to examine its primarily historical aspects a new academic discipline, cimrmanology, was established. J. Cimrman won the contest for the greatest Czech man organised by a TV station licensed by $\mathrm{BBC}$. The station later stated that a person that does not exist cannot be the winner. This ended with a wave of protests of dissatisfied Czech society (Szczygiel, 2012).

There even emerged a specific type of humour - cimrmanian humour - which required considerable erudition and wit from the receiver. J. Cimrman became so overwhelmingly popular that he "surpassed the boundaries set by the creative act" (Tarajło-Lipowska, 2010, p. 387). This resulted from the fact that all Czech people played his game. Despite the fact that one of the character's creators, $\mathrm{L}$. Smoljak, died in 2010, J. Cimrman's legend continues to thrive and is recreated by other artists. Lectures are still delivered by cimrmanologists and exhibitions concerning J. Cimrman are still displayed in museums. His statues are erected and streets are named in his memory (Szczygiel, 2012).

A film about this famous character, Jara Cimrman Lying, Sleeping (cs. Jára Cimrman ležící, spíci) was made in 1983. This motion picture is a mystification, which Luboš Ptáček considered as one of comedy subgenres (Ptáček, 2000, p. 267). In Czech Republic the hoax is such a popular form that a category for it has been distinguished in the country's cinematography. Jara Cimrman Lying, Sleeping concerns a few most important "facts" from the life of the genius. There are two plots: the modern one, in which a group of tourists is visiting Jára Cimrman's Museum, and a biographical one, in which J. Cimrman's adventures are presented. What one can learn from the film is that this national hero lived the turn of $19^{\text {th }}$ and $20^{\text {th }}$ century, and was an active inventor and writer who helped many well-known artists create their art. He was also the counsellor of the Archduke Franz Ferdinand 
of Austria, whom he urged to form Austria-Hungary-Czech monarchy. After he failed in these attempts he resigned from his position to take up residence in a small village where he started to teach in the local school, which later became Jara Cimrman's Museum. For the last time he was seen there in the year 1914. In the end the two plots connect and it turns out that J. Cimrman was the elderly woman that showed the tourists around the museum. The film, similarly to Cimrman's theatre, is full of black humour, nonsensical stories, pataphysical mystifications and Dadaistic visions. It operates with the sense of humour that is now known as Cimrmanian (Hames, 2009, pp. 320-321).

Another mystification film is Oil Gobblers from 1988, which tells the story of a group of scientists. They discover a new species; the animals that dwell in industrial places such as mines and quarries, make strange sounds and feed on toxic fumes. The film includes motifs that are characteristic for the structure of documentaries, for instance obstacles that the scientists stumble upon during the animals' observation, the researchers' mistakes, the successful filming of Oil Gobblers during their and, finally, the struggle for survival of some of the animals (Hames, 2009, p. 330).

An example of a hoax on the scale of the whole country was the provocation of two Film and TV School of the Academy of Performing Arts in Prague (FAMU) students, who used the money from the Ministry of Culture scholarship to make a film. The directors, Vít Klusák and Filip Remunda's idea was to run an advertisement campaign a product that did not exist. The product was the supermarket Czech Dream (cs. Český Sen), whose nonexistence was even suggested in the name. A billboard that showed the front elevation of the store was put up in the district of Letňany in Prague. They launched a whole campaign, which included TV and radio spots and 400 illuminated billboards; 200,000 flyers promoting Czech Dream brand. An advertising song that included a choir was recorded and a website was created. The slogan was "Don't Go, Don't Rush, Don't Spend". Four thousand people came to the opening of the supermarket. The end of the film it is shown how all the deceived people are leaving and saying, often in obscene manner, that they feel cheated and that the manipulation showed nothing of particular interest and that the public money spent on it was wasted. Some simply admitted that they fell victim to a joke. Everything was filmed and presented to the audience as a documentary about the greatest Czech hoax. The directors intended to show the modern consumptive machinery and how advertising worked. They proved it to people that something that does not exist can be advertised and that the promotion will be effective nevertheless. The film showed ordinary Czechs who spend whole days in the supermarket and considered it their favourite spare time activity. The people behind the campaign were also interviewed and asked about its moral aspects. Many of them admitted that the whole operation was questionable ethically, since it assumed selling a nonexistent product, yet still they would participate to benefit from it. Czech Dream triggered a social debate about global lifestyle changes after 1989, the unlimited consumerism, the ethics of mass media and Czech Republic joining the European Union (http://www.ceskatelevize.cz/ specialy/ceskysen/en). 
In 2002 Petr Zelenka created a mockumentary - Year of the Devil (cs. Rok D'abla). The film was a mystification prepared by himself, Danish journalist Jan Prent, musicians Jaromir Nohavica, Karel Plíhal, Jaz Coleman and the band Čechomor: Frantisek Černý, Radek Pobořil, Michal Pavlík i Radek Klučka. The film concerns the collaboration of these musicians with paranormal events. Even the first meeting of the artists seems to be some mysterious destiny. When they perform, they see angels, ghosts and dead people. They do mystical rituals, heal people, each concert becomes an extraordinary experience, and in the end one of them undergoes spontaneous combustion. The musicians do not understand anything of what is happening around them, are horrified by the changes within them and can no longer recognise what is real and what is not. Year of the Devil is filmed in such a manner as to appear to be a documentary. Three scenes at the beginning show people from different places in the world speaking about the spontaneous combustion of their relatives and, similarly to numerous following scenes, are made with an amateur video camera. The film shows interviews with musicians during which they look into the camera. There are concert reports, backstage scenes show the work of the cameraman. P. Zelenka also made another mockumentary, Mňága - Happy End (1996) about Mňága a Žd'orp band. What makes Year of the Devil different, though, is that it shows real people, famous contributors to Czech culture: a musician and poet J. Nohavica and the popular band Čechomor.

Nowadays' Czech hoaxes are similar to happenings that aim to amuse the audience. In the case of J. Cimrman one can, without doubt, speak of a remarkable cultural phenomenon, as he constitutes the game that is played by the whole nation. His character is in the centre of many consecutive mystifications. The adventures of J. Cimrman are made up not only by the creators alone, but by all Czechs. The plebiscite that the character won demonstrates that he in fact is a hero of Czech society.

That the phenomenon of mystification is present in Czech culture is proved by the number of the mystifications itself. The artists often relate to them, because they are an unusual means to express oneself and give a large spectrum of kinds of humour to use and gain attention. Czech films are known for their absurd sense of humour - the Polish saying "nobody knows anything - Czech film" definitely has some truth in it. This is what mystifications that include J. Cimrman are like: surrealistic, Dadaistic, refusing to obey laws of logic. There are sudden turns in the plot and the effects of actions are grotesque and inadequate to a fault. This is the reason why Czech people construe mystification as comedy genres: it is their way to amuse an audience.

\section{REFERENCES}

\section{Bibliography}

Boese, A. (2003). Nieznane archiwa mistyfikacji [The Museum of Hoaxes]. Warszawa: Wydawnictwo Amber. Castagnaro, M. (2009). Embellishment, Fabrication, and Scandal: Hoaxing and the American Press. Carnegie: Carnegie Mellon University.

Hames, P. (2009). Czechostowacka Nowa Fala [Czechoslovak New Wave]. Gdańsk: Wydawnictwo słowo / obraz terytoria. 
Joniak, A. (2009). Wielka mistyfikacja - fenomen praskiego teatru Járy Cimrmana, [The Great Mistification - phenomenon of Jára Cimrman Theatre in Prague ]. In: J. Kościukiewicz, J. Korybut, J. (Eds.) (p. 203), Jezyk, kultura i literatura Czech [Czech language, literature and culture]. Racibórz: Wydawnictwo "Pro".

Markiewicz, H. (2003). Zabawy literackie dawne i nowe [Plays with literature: in the past and nowadays]. Kraków: Wydawnictwo Universitas.

Ptáček, L. (2000). Panorama českého filmu [Panorama od Czech movie]. Olomouc: Rubico.

Smoljak, L., Svěrák Z. (1993). To nejlepší ze Smoljaka, Svěráka a Járy Cimrmana, [The best of Smoljak, Svěrák and Jára Cimrman]. Praha: Exact Service.

Smoljak, L., Svěrák Z., Weigel J. (2009). Jára Cimrman: Génius, který se neproslavil [Jára Cimrman: Genius who wasn't famous]. Brno: Computer Press.

Tarajło-Lipowska, Z. (2010). Historia literatury czeskiej [History of Czech literature] Wrocław: Zakład Narodowy im. Ossolińskich-Wydawnictwo we Wrocławiu.

\section{Netography}

Szczygieł, M. Fatszywa polędwica. http:// wyborcza.pl/1,76842,8908148,Falszywa_poledwica.html Retrieved: 1.02.2013.

http://www.ceskatelevize.cz/specialy/ceskysen/en Retrieved: 1.02.2013.

\section{Filmography}

Klusák, V., Remunda F. (2004). Český sen.

Smoljak, L., Svěrák Z. (1983). Jára Cimrman ležící, spicí.

Svěrák, J. (1988). Ropáci.

Zelenka, P. (1996). Mnága - Happy End.

Zelenka, P. (2002). Year of the Devil. 